\title{
Impact of the National Health Fund policy on hormone treatment for prostate cancer in Jamaica
}

\author{
Belinda F. Morrison, ${ }^{1}$ William D. Aiken, ${ }^{1}$ and Marvin E. Reid ${ }^{2}$
}

Suggested citation Morrison BF, Aiken WD, Reid ME. Impact of the National Health Fund policy on hormone treatment for prostate cancer in Jamaica. Rev Panam Salud Publica. 2011;29(6):404-8.

ABSTRACT Objective. To compare the proportion of patients choosing surgical versus medical castration to treat prostate cancer, before and after the National Health Fund (NHF) of Jamaica began to subsidize hormone therapy.

Methods. A retrospective review was performed at the University Hospital of the West Indies (UHWI), Jamaica. The pathology database at UHWI was searched to identify patients who had prostate biopsies between January 2000 and December 2007. These were combined with records of biopsies at external institutions. Medical records of all patients with positive prostate biopsies were reviewed to determine if they had received androgen deprivation therapy (ADT). Patients were classified as having had surgical castration (bilateral orchiectomy) or medical castration. Chi-square statistics were used to determine the difference in proportions between those choosing medical versus surgical castration before and after March 2005, when the NHF began offering subsidies for ADT drugs.

Results. Of the 1529 prostate biopsies performed during the study period, $680(44.0 \%)$ cases of prostate cancer were diagnosed. Of these, 458 patients underwent ADT and had complete records available for analysis. The mean patient age was 72 years. During the entire study period, surgical castration was performed in 265 patients $(58.0 \%)$ and medical castration in $193(42.0 \%)$. A greater proportion of orchiectomies were performed before March 2005, rather than after $(\mathrm{P}<0.001)$. Estrogens were the most common method of medical castration used before the NHF subsidy became available (62.0\%); while luteinizing hormone-releasing hormone analogues (38.0\%) and antiandrogens (36.5\%) were most often chosen afterwards. Conclusions. Surgical castration was more common than medical castration before March 2005. After the NHF began to subsidize the cost of drugs for hormone therapy, medical castration was chosen more often. Increased access to drugs for hormone therapy has changed treatment patterns in Jamaica.

Key words Prostatic neoplasms; orchiectomy; androgen antagonists, therapeutic use; prescription fees; Jamaica.

Androgen deprivation therapy (ADT) remains the treatment of choice for advanced and metastatic prostate cancer (1). Since 1941, when the palliative effects of castration and estrogens on

\footnotetext{
1 Department of Surgery, University of the West Indies, Kingston, Jamaica. Send correspondence to Belinda Morrison, bfmorrison11@hotmail.com

2 Sickle Cell Unit, University of the West Indies, Kingston, Jamaica.
}

metastatic prostate cancer were first described (2), this type of treatment has become widespread. ADT improves survival for patients with locally advanced disease previously treated with external beam radiation (3). A practice variation that has gained acceptance is the use of ADT in patients with rising prostate specific antigen (PSA) after curative therapy (4).
ADT may be achieved via surgical or medical means (1). The decision about the type of ADT chosen depends on a number of variables, including treatment costs, adverse effects, patient age, and availability of therapeutic options. In the United States of America, where prostate cancer screening is becoming routine, there has been a stage migration, with most patients presenting with 
localized prostate cancer (1). Despite this, the use of ADT has increased due to failure of local therapy, which can be identified by rising PSA in patients (1). In Jamaica, widespread screening has not been adopted yet, and therefore, most cases of prostate cancer are locally advanced or metastatic at presentation. As a result, ADT use is still the norm in Jamaica.

Surgical castration (bilateral orchiectomy) was the first method of ADT described (2); however, this procedure is permanent, has deleterious effects on sexual function, and affects patient quality of life $(5,6)$. Conversely, medical castration is reversible, but treatment is expensive. In the United States, there has been a decline in surgical ADT for prostate cancer (7).

In 2003, the National Health Fund (NHF) was established in Jamaica to provide substantial discounts (around 60\%) on specific medications used to treat certain medical conditions. In 2005, the NHF added to its approved list five ADT drugs used to treat prostate cancer: bicalutamide, oral conjugated estrogens, goserelin, leuprolide, and flutamide. Later, cyproterone acetate, and the taxol group of compounds were added. In March 2005, the NHF began providing significant subsidies for these medications, facilitating greater access to a variety of newer treatments.

The present study sought to compare the proportion of patients choosing surgical versus medical castration before and after the introduction of the NHF's subsidy for ADT drugs in Jamaica.

\section{MATERIALS AND METHODS}

The Pathology Database at the University Hospital of the West Indies (UHWI), Mona, Jamaica, was reviewed to identify all patients with prostate biopsies during the January 2000-December 2007 period. All patients whose local biopsies were positive were combined with those of other patients from external institutions, including a private pathology laboratory and the National Public Health Laboratory in Kingston, Jamaica. The relevant records of patients with positive prostate biopsies were reviewed, and those who underwent ADT during the study period were included.

Patients were classified as having had surgical castration (bilateral orchiectomy) or medical castration. The date of initiation of therapy and the specific type of ADT were recorded. March 2005 marked the point at which the NHF began to subsidize drugs for medical ADT. Ethical approval was obtained from the Ethics Department, Faculty of Medical Sciences, University of the West Indies, Kingston, Jamaica.

\section{Statistical analyses}

Values are expressed as counts or proportions. Associations between categorical variables were performed with $\chi^{2}$ statistics using Stata statistical software, version 10 (StataCorp LP, College Station, Texas, United States). For continuous outcome variables, t-test was used to determine differences in means. Economic costs of health interventions were expressed in US\$ as of February 2011, using the Bank of Jamaica monthly exchange rate (8).

\section{RESULTS}

During the January 2000-December 2007 period, a total of 680 cases of prostate cancer were diagnosed from 1529 prostate biopsies $(44.0 \%)$ performed at the UHWI. When combined with the positive biopsies from the other institutions, a total of 458 patients underwent ADT for prostate cancer and had records available for study.

TABLE 1. Age distribution of patients treated with androgen deprivation at the University Hospital of the West Indies, Jamaica, before and after the National Health Fund began to subsidize drugs for hormone therapy, 2000-2007

\begin{tabular}{|c|c|c|}
\hline \multirow[b]{3}{*}{ Castration type } & \multicolumn{2}{|c|}{ Period } \\
\hline & $\begin{array}{c}\text { Before subsidy } \\
\text { (January 2000-February 2005) }\end{array}$ & $\begin{array}{c}\text { After subsidy } \\
\text { (March 2005-December 2007) }\end{array}$ \\
\hline & Mean age in years $\left(\mathrm{SD}^{\mathrm{a}}\right)$ & Mean age in years (SD) \\
\hline Medical & $70.7(9.3)$ & $73.5(8.3)$ \\
\hline Surgical & $73.4(9.2)$ & $74.4(8.7)$ \\
\hline
\end{tabular}

TABLE 2. Methods of castration chosen by 458 patients being treated for prostate cancer at University Hospital of the West Indies, Jamaica, before and after the National Health Fund began to subsidize drugs for hormone therapy, 2000-2007

\begin{tabular}{|c|c|c|c|c|c|c|}
\hline \multirow{3}{*}{$\begin{array}{l}\text { Method of } \\
\text { castration }\end{array}$} & \multicolumn{4}{|c|}{ Period } & & \\
\hline & \multicolumn{2}{|c|}{$\begin{array}{c}\text { Before subsidy } \\
\text { (January 2000-February 2005) }\end{array}$} & \multicolumn{2}{|c|}{$\begin{array}{c}\text { After subsidy } \\
\text { (March 2005-December 2007) }\end{array}$} & \multicolumn{2}{|c|}{ Total } \\
\hline & No. & $\%$ & No. & $\%$ & No. & $\%$ \\
\hline Medical & 79 & 39.4 & 114 & 57.6 & 193 & 42.1 \\
\hline Surgical & 181 & 60.6 & 84 & 42.4 & 265 & 57.9 \\
\hline Total & 260 & 100.0 & 198 & 100.0 & 458 & 100.0 \\
\hline
\end{tabular}


TABLE 3. Methods of medical castration at the University Hospital of the West Indies, Jamaica, before and after the National Health Fund began to subsidize drugs for androgen deprivation therapy, 2000-2007

\begin{tabular}{|c|c|c|c|c|c|}
\hline \multirow{3}{*}{$\begin{array}{l}\text { Method of } \\
\text { castration }\end{array}$} & \multicolumn{4}{|c|}{ Period } & \multirow[b]{3}{*}{ Total } \\
\hline & \multicolumn{2}{|c|}{$\begin{array}{c}\text { Before subsidy } \\
\text { (January 2000-February 2005) }\end{array}$} & \multicolumn{2}{|c|}{$\begin{array}{c}\text { After subsidy } \\
\text { (March 2005-December 2007) }\end{array}$} & \\
\hline & No. of exposures & $\%$ & No. of exposures & $\%$ & \\
\hline \multicolumn{6}{|l|}{ Antiandrogens } \\
\hline Cyproterone acetate (Androcur $\left.{ }^{\circledR}\right)$ & 22 & 19.3 & 73 & 29.3 & 95 \\
\hline Bicalutamide $\left(\right.$ Casodex $\left.^{\circledast}\right)$ & 5 & 4.4 & 18 & 7.2 & 23 \\
\hline Flutamide & 3 & 2.6 & 0 & 0.0 & 3 \\
\hline Total antiandrogens & 30 & 26.3 & 91 & 36.5 & 121 \\
\hline \multicolumn{6}{|l|}{ Estrogens } \\
\hline Conjugated estrogen (Premarin ${ }^{\circledR}$ ) & 70 & 61.4 & 60 & 24.1 & 130 \\
\hline Honvan $^{\circledR}$ & 1 & 0.9 & 1 & 0.4 & 2 \\
\hline Progynova $^{\circledR}$ & 0 & 0.0 & 1 & 0.4 & 1 \\
\hline Total estrogens & 71 & 62.3 & 62 & 24.9 & 133 \\
\hline \multicolumn{6}{|l|}{$\mathrm{LHRH}^{\mathrm{a}}$ analogues } \\
\hline Leuprolide acetate $\left(\right.$ Lucrin $\left.^{\circledR}\right)$ & 1 & 0.9 & 0 & 0.0 & 1 \\
\hline Goserelin (Zoladex ${ }^{\circledR}$ ) & 12 & 10.5 & 94 & 37.8 & 106 \\
\hline Total LHRH analogues & 13 & 11.4 & 94 & 37.8 & 107 \\
\hline Ketoconazole & 0 & 0.0 & 2 & 0.8 & 2 \\
\hline Total & 114 & & 249 & & 363 \\
\hline
\end{tabular}

a Luteinizing hormone-releasing hormone.

male cancer-related deaths in Jamaica (10). Since the burden of prostate cancer and ADT use in Jamaica are quite high, this issue deserves attention. The present study indicates that $67 \%$ of patients diagnosed with prostate cancer between 2000 and 2007 received a form of ADT. This study also showed that ADT use in Jamaica has changed since the introduction of the NHF subsidy, with surgical castration being chosen less frequently than before. This is in keeping with international reports, where surgical castration has fallen out of favor (7).

With the introduction of PSA testing in Jamaica in 1991, more cases of prostate cancer are being diagnosed. However, since screening is not widespread, the typical stage migration seen in other countries has still not taken place in Jamaica. Therefore, since more patients are diagnosed with advanced or metastatic disease, the need for ADT is highly relevant to treatment.

The mechanism of action for ADT in prostate cancer treatment is based on the fact that most prostate cancer cells are androgen dependent (11). Testosterone is converted into dihydrotestosterone (DHT), its active metabolite, in cells. DHT binds to the androgen receptor and is transduced into the nucleus, where it activates androgen-dependent genes. This results in cell growth. ADT results in apoptosis (programmed cell death) of androgen-sensitive cells.

\section{Surgical castration}

As stated earlier, surgical castration has been the preferred method of ADT for many decades. It is achieved by a quick, ambulatory surgical procedure at a relatively low cost. It eliminates the potential problems of compliance with medical therapy. After surgical castration, serum testosterone falls quickly to castrate levels (<10 ng/ml) (1). Progression-free survival is improved in patients with prostate cancer treated with surgical castration versus placebo (12).

The emotional and psychological impact of the procedure is a great concern to many men treated with ADT. Several studies have suggested that if given a choice, most men will choose medical over surgical therapy (13). Low testosterone levels result in hot flashes, weight gain, mood lability, fatigue, gynecomastia, cognitive changes, loss of libido, and erectile dysfunction. In addition, there is reduced bone mineral density, which may increase the risk of fractures. These disadvantages inspired the search for agents that were effective, but with low morbidity.

\section{Options for medical castration}

Medical castration may be achieved by estrogens, antiandrogens, and agonists or antagonists of luteinizing hormonereleasing hormone (LHRH). All cate- gories of ADT drugs are available in Jamaica and have similar adverse effects due to hypogonadism.

Diethylstilboestrol was the original estrogen used for prostate cancer treatment. The mechanisms of action include inhibiting LHRH release by the hypothalamus, inhibition of adrenal androgens via hepatic mechanisms, and direct cytotoxic effects. Although this drug is cheap, it is reported to cause significant cardiovascular toxicity, such as deep vein thromboses, myocardial infarctions, pulmonary embolism, and stroke (14, 15). These effects are due to the increased hepatic production of coagulation factors. In randomized controlled trials, patients treated with diethylstilboestrol had less prostate cancer mortality, but more cardiovascular mortality than those treated with bilateral orchiectomy or LHRH analogues (16).

The present study showed that prior to March 2005, conjugated estrogens were the most common agent for medical castration at the UHWI. However, after March 2005, this agent was the least prescribed. Data from the NHF for islandwide claims between 2003 and 2008 suggest that conjugated estrogens were the least-prescribed agent for medical castration. This may have been confounded by the poor availability of the drug at certain pharmacies island-wide. Estrogens may cause gynecomastia, nipple tenderness, and breast pain. Unlike the other forms of ADT, estrogens protect against osteoporosis (17). Although estrogens are still widely used in Jamaica, there is a paucity of cardiovascular risk outcomes locally. However, data suggest an effectiveness of parenteral estrogens in androgenindependent prostate cancer, with no thromboembolic complications (18).

Antiandrogens may be used as monotherapy or combined with an LHRH analogue for combined androgen blockade (19). Antiandrogens may be classified as steroidal (cyproterone acetate or megestrol acetate) or nonsteroidal (bicalutamide, nilutamide, or flutamide). Steroidal antiandrogens directly inhibit peripheral receptors, but also have a progestational and antigonadotropic effect. Nonsteroidal antiandrogens inhibit only peripheral androgen receptors. Bicalutamide has the advantage of maintaining potency in men with prostate cancer (20). NHF data claims from the 2003-2008 period report that cyproterone acetate was the most frequently prescribed drug for 
medical castration in Jamaica. In the present study, this agent was the most commonly prescribed antiandrogen.

In many countries, LHRH analogues have largely replaced other hormonal therapies for prostate cancer. LHRH is normally produced in the hypothalamus and regulates testosterone production by the testis. LHRH stimulates the release of LH from the pituitary. The latter stimulates increased testosterone production from Leydig cells in the testis. LHRH agonists bind to receptors in the pituitary. The initial response is a surge in LH secretion for 1-2 weeks that causes a "testosterone flare" (21). With negative feedback, there is eventual suppression of testosterone secretion. LHRH analogues are administered as depot preparations and may be given at 1-, 3-, or even 12-month intervals. This stands to improve compliance.

The present study revealed the LHRH analogue, Goserelin, was the most frequently prescribed method of medical castration after March 2005. NHF islandwide claims report that Goserelin is the second most-prescribed method of medical castration.

\section{Cost comparison}

All forms of medical castration represent expensive forms of androgen suppression compared to bilateral orchiectomy. At the UHWI, bilateral orchiectomy costs US\$133. Costs for medical castration in Jamaica prior to March 2005 were US\$ 956-US\$ 7491 annually per patient (LHRH-Goserelin, US\$ 3 655; bicalutamide, US\$ 7 491; cyproterone acetate, US\$2 064; conjugated estrogens, US\$1471; and flutamide, US\$ 956). The NHF subsidy reduced the annual drug cost to the patient to US\$42.67-US\$ 3199 annually (LHRH-Goserelin, US\$ 140; bicalutamide, US\$ 3199; cyproterone acetate, US\$ 975; conjugated estrogens, US\$ 1 157; and flutamide, US\$ 43).

In some cases, medical castration may offer a cost-savings over surgical castration. Given the possibility for use of intermittent therapy in patients with castrate-sensitive prostate cancer (22), medical castration may allow for mitigation of adverse effects, offering a potential cost-savings, without difference in survival.

\section{Study limitations}

One limitation of the present study was the data source. Data were retrieved from the Pathology Department at the UHWI, a tertiary teaching hospital serving the parishes of Kingston and St. Andrew. These parishes contain approximately $24 \%$ of the adult male population of Jamaica (23). The severity of the disease could be overestimated in a sample from such a facility. In addition, the clinical stage of the disease-which could affect treatment choice-was not taken into account.

\section{Conclusions}

In Jamaica, increased access to ADT drugs through the NHF has changed treatment patterns for patients with prostate cancer. Since the introduction of the NHF subsidy for medical ADT, medical castration has become the preferred treatment. Health policy decisions facilitating greater access to newer types of treatment will result in greater utilization, which may, in turn, improve health outcomes.

\section{REFERENCES}

1. Loblaw DA, Mendelson DS, Talcott JA, Virgo KS, Somerfield MR, Ben-Josef E, et al. American Society of Clinical Oncology recommendations for the initial hormonal management of androgen-sensitive metastatic, recurrent, or progressive prostate cancer. J Clin Oncol. 2004;22(14):2927-41.

2. Huggins C. Effect of Orchiectomy and Irradiation on Cancer of the Prostate. Ann Surg. 1942;115(6):1192-200.

3. Bolla M, Collette L, Blank L, Warde P, Dubois $\mathrm{JB}$, Mirimanoff RO, et al. Long-term results with immediate androgen suppression and external irradiation in patients with locally advanced prostate cancer (an EORTC study): a phase III randomised trial. Lancet. 2002; 360(9327):103-6.

4. Zincke $\mathrm{H}$, Oesterling JE, Blute ML, Bergstralh EJ, Myers RP, Barrett DM. Long-term (15 years) results after radical prostatectomy for clinically localized (stage T2c or lower) prostate cancer. J Urol. 1994;152(5 Pt 2): 1850-7.

5. Cassileth BR, Soloway MS, Vogelzang NJ, Chou JM, Schellhammer PD, Seidmon EJ, et al. Quality of life and psychosocial status in stage D prostate cancer. Zoladex Prostate Cancer Study Group. Qual Life Res. 1992;1(5): 323-9.
6. Lucas MD, Strijdom SC, Berk M, Hart GA. Quality of life, sexual functioning and sex role identity after surgical orchidectomy in patients with prostatic cancer. Scand J Urol Nephrol. 1995;29(4):497-500.

7. Barry MJ, Delorenzo MA, Walker-Corkery ES, Lucas FL, Wennberg DC. The rising prevalence of androgen deprivation among older American men since the advent of prostate-specific antigen testing: a population-based cohort study. BJU Int. 2006;98(5): 973-8.

8. Bank of Jamaica. Exchange rates. Available from: http://www.boj.org.jm/exchange rates_month.php. Accessed on 28 March 2011.

9. Gibson T, Blake G, Hanchard B, Waugh N, McNaughton D. Age-specific incidence of cancer in Kingston and St. Andrew, 19982002. West Indian Med J. 2008;57(2):81-9.

10. Blake G, Hanchard B, Mitchell K, Simpson D, Waugh N, Wolff C, et al. Jamaica cancer mortality statistics, 1999. West Indian Med J. 2002;51(2):64-7.

11. Klotz L. Hormone therapy for patients with prostate carcinoma. Cancer. 2000;88(12 Suppl):3009-14.

12. Byar DP. Proceedings of the Veterans Administration Cooperative Urological Research
Group's studies of cancer of the prostate. Cancer. 1973;32(5):1126-30.

13. Cassileth BR, Soloway MS, Vogelzang NJ, Schellhammer PS, Seidmon EJ, Hait HI, et al. Patients' choice of treatment in stage D prostate cancer. Urology. 1989;33(5 Suppl): $57-62$.

14. Byar DP, Corle DK. Hormone therapy for prostate cancer: results of the Veterans Administration Cooperative Urological Research Group studies. NCI Monogr.1988(7): 165-70.

15. Blackard CE, Doe RP, Mellinger GT, Byar DP. Incidence of cardiovascular disease and death in patients receiving diethylstilbestrol for carcinoma of the prostate. Cancer. 1970;26(2): $249-56$.

16. Leuprolide versus diethylstilbestrol for metastatic prostate cancer. The Leuprolide Study Group. N Engl J Med. 1984;311(20): 1281-6.

17. Ockrim JL, Lalani EN, Banks LM, Svensson WE, Blomley MJ, Patel S, et al. Transdermal estradiol improves bone density when used as single agent therapy for prostate cancer. J Urol. 2004;172(6 Pt 1):2203-7.

18. Bland LB, Garzotto M, DeLoughery TG, Ryan CW, Schuff KG, Wersinger EM, et al. Phase II study of transdermal estradiol in androgenindependent prostate carcinoma. Cancer. 2005;103(4):717-23. 
19. Maximum androgen blockade in advanced prostate cancer: an overview of the randomised trials. Prostate Cancer Trialists' Collaborative Group. Lancet. 2000;355(9214): $1491-8$.

20. Migliari R, Muscas G, Usai E. Effect of Casodex on sleep-related erections in patients with advanced prostate cancer. J Urol. 1992;148(2 Pt 1):338-41.
21. Kimura K, Markowski M, Bowen C, Gelmann EP. Androgen blocks apoptosis of hormonedependent prostate cancer cells. Cancer Res. 2001;61(14):5611-8.

22. Abrahamsson PA. Potential benefits of intermittent androgen suppression therapy in the treatment of prostate cancer: a systematic review of the literature. Eur Urol. 2010;57(1): $49-59$.
23. Wilks $\mathrm{R}$, Younger $\mathrm{N}$, Tulloch-Reid $\mathrm{M}$, McFarlane S, Francis D. Jamaica health and lifestyle survey, 2007-2008. Kingston: Epidemiology Research Unit; 2008.

Manuscript received on 15 January 2011. Revised version accepted for publication on 4 April 2011

RESUMEN Objetivo. Comparar la proporción de pacientes que eligen la castración quirúrgica frente a la castración farmacológica para tratar el cáncer de próstata, antes y después de la creación de un subsidio del Fondo Nacional de Salud (NHF, por sus siglas en

Repercusión de un subsidio del Fondo Nacional de Salud en la hormonoterapia para el cáncer de próstata en Jamaica inglés) de Jamaica destinado a cubrir los costos de la hormonoterapia.

Métodos. Se llevó a cabo un examen retrospectivo en el Hospital Universitario de las Indias Occidentales, Jamaica. Se efectuó una búsqueda en la base de datos de enfermedades de dicho hospital para identificar a los pacientes a quienes se les había practicado una biopsia de próstata entre enero del 2000 y diciembre del 2007. Los datos se combinaron con los registros de biopsias llevadas a cabo en instituciones externas. Se estudiaron las historias clínicas de todos los pacientes con resultados positivos en la biopsia de próstata para determinar si habían recibido tratamiento de supresión androgénica. Los pacientes se clasificaron en dos grupos, según se hubieran tratado mediante castración quirúrgica (orquiectomía bilateral) o farmacológica. Se usó la prueba de la ji al cuadrado para determinar la diferencia en las proporciones entre los pacientes que escogieron la castración quirúrgica y los que escogieron la opción farmacológica antes y después de marzo del 2005, la fecha en la que el NHF empezó a subsidiar los medicamentos de supresión androgénica.

Resultados. Entre las 1529 biopsias de próstata realizadas durante el período de estudio, hubo 680 (44,0\%) casos con diagnóstico de cáncer de próstata. De estos, 458 pacientes habían recibido tratamiento de supresión androgénica y se disponía de sus registros completos para el análisis. La edad media de los pacientes fue de 72 años. Durante el período de estudio, se les practicó castración quirúrgica a 265 pacientes (58,0\%) y castración farmacológica a 193 (42,0\%). La proporción de orquiectomías fue mayor antes de marzo del 2005 que después de esa fecha $(P<0,001)$. Los estrógenos fueron el método de castración farmacológica más común antes de la creación del subsidio del NHF $(62,0 \%)$; a partir de ese momento se eligieron con mayor frecuencia los análogos de la hormona liberadora de la hormona luteinizante $(38,0 \%)$ y los antiandrógenos $(36,5 \%)$

Conclusiones. La castración quirúrgica era más común que la castración farmacológica antes de marzo del 2005. Después de que el NHF empezó a subsidiar el costo de los medicamentos para el tratamiento hormonal, la opción escogida con más frecuencia fue la castración farmacológica. El mayor acceso a los medicamentos usados en la hormonoterapia ha cambiado los patrones de tratamiento del cáncer de próstata en Jamaica.

Palabras clave Neoplasias de la próstata; orquiectomía; antagonistas de andrógenos, uso terapéutico; honorarios por prescripción de medicamentos; Jamaica. 